\title{
Potato brown rot incidence and severity under different management and amendment regimes in different soil types
}

\author{
Nevain A. S. Messiha - Ariena H. C. van Bruggen - Anne D. van Diepeningen • \\ Oscar J. de Vos · Aad J. Termorshuizen · N. N. A. Tjou-Tam-Sin •
}

J. D. Janse

Received: 13 September 2006/Accepted: 7 May 2007/Published online: 14 June 2007

(c) KNPV 2007

\begin{abstract}
Ralstonia solanacearum race 3 biovar 2, the causative agent of potato brown rot (bacterial wilt), is an economically important disease in tropical, subtropical and temperate regions of the world. In view of previous reports on suppression of the disease by organic amendments, and the expansion of organic agriculture, it was timely to compare the effects of organic and conventional management and various amendments on brown rot development in different soils (type: sand or clay; origin: Egypt or the Netherlands). Brown rot infection was only slightly
\end{abstract}

N. A. S. Messiha - A. H. C. van Bruggen .

A. D. van Diepeningen - O. J. de Vos .

A. J. Termorshuizen

Biological Farming Systems Group, Marijkeweg 22, 6709

PG Wageningen, The Netherlands

N. A. S. Messiha - N. N. A. Tjou-Tam-Sin .

J. D. Janse ( $\square)$

Department of Bacteriology, Plant Protection Service

(PD), Geertjesweg 15, 6706 EA Wageningen,

The Netherlands

e-mail: j.d.janse@minlnv.nl

N. A. S. Messiha

Potato Brown Rot Project, Agricultural Research Centre,

Cairo, Egypt

J. D. Janse

Department of Bacteriology, Plant Protection Service

(PD), P.O. Box 9102, 6700 HC Wageningen,

The Netherlands reduced in organically compared to conventionally managed sandy soils from Egypt, but organic management significantly increased disease incidence and pathogen survival in Dutch sandy and clay soils, which correlated with high DOC contents in the organic Dutch soils. There was no correlation between disease incidence or severity and bacterial diversity in the potato rhizosphere in differently managed soils (as determined by 16S DGGE). NPK fertilization reduced bacterial wilt in conventional Egyptian soils but not in Dutch soils. Cow manure amendment significantly reduced disease incidence in organic Dutch sandy soils, but did not affect the bacterial population. However, cow manure did reduce densities of $R$. solanacearum in Egyptian sandy soils, most probably by microbial competition as a clear shift in populations was detected with DGGE in these and Dutch sandy soils after manure amendment. Amendment with compost did not have a suppressive effect in any soil type. The absence of a disease suppressive effect of mineral and organic fertilization in Dutch clay soils may be related to the already high availability of inorganic and organic nutrients in these soils. This study shows that the mechanism of disease suppression of soil-borne plant pathogens may vary strongly according to the soil type, especially if quite different types of soil are used.

Keywords Calcium · DGGE · Organic farming · Potassium $\cdot$ Ralstonia solanacearum 


\section{Introduction}

Ralstonia solanacearum causes a vascular disease in many different host plants including many economically important crops and in more than 40 countries. Five races are distinguished: race 1, biovar 1, 3 and 5 having a broad host range, race 2 , affecting bananas, and race 3 biovar 2 (phyllovar 1 , sequevar 1 ) infecting primarily potato and tomato. The disease is generally referred to as 'bacterial wilt', but in potato it is also called 'brown rot' (Elphinstone 2005).

In some areas, naturally suppressive soils have been reported (see for a review e.g. Hayward 1991). The influence of soil type on disease severity has been repeatedly established (Moffett et al. 1983; van Elsas et al. 2000), but the actual effects are controversial and depend on geographical location, strains (race, biovar) of the pathogen, and crops involved. In some cases, bacterial wilt was more severe on welldrained sandy loams (French 1994; Hayward 1991), and the decline rate of the pathogen was higher in clay loam than in sandy loam (Moffett et al. 1983). In other cases, the disease was most severe on heavy clay-loam soil (Kelman 1953). Thus, suppressiveness of soil towards bacterial wilt may be related to other factors than soil texture, such as $\mathrm{pH}$, organic matter content and microbial communities (van Elsas et al. 2005). Disease suppression was lost after soil treatment with methyl bromide or heat, indicating that a biological principle was the main factor.

Control of bacterial wilt in areas conducive to the disease is difficult: there are no curative chemicals, resistance breeding has only been reasonably successful against race 1 of the pathogen and diverse cultural measures (including the use of certified seed, wide rotations with non-host crops and careful water management) have had only limited success (Kelman 1953; Hartman and Elphinstone 1994; French 1994).

Inorganic soil amendments have sometimes shown promising results both in pot experiments and in the field, but in other cases there was little effect. An increase or decrease in $\mathrm{pH}$ reduced wilt in tobacco, tomato and eggplant when sulphur (acidification) or lime (neutralization) was added, especially in relatively acid, fine sandy soils (Kelman 1953; Michel and Mew 1998). However, for potato on sandy loam soils with high organic matter content this was not effective. A high nitrogen dose reduced bacterial wilt in sandy soils; nitrates were more effective than ammoniacal compounds (Kelman 1953; Michel and Mew 1998). Soil amendment with NPK at $100 \mathrm{~kg} \mathrm{ha}^{-1}$ significantly decreased bacterial wilt incidence on potato and increased potato yield (Lemaga et al. 2005). Soil fertilization and amendment of soil with high inputs of urea and $\mathrm{CaO}$ or $\mathrm{MgO}$ also significantly decreased populations of $R$. solanacearum populations (Elphinstone and Aley 1993; Michel et al. 1997).

Apart from inorganic amendments, organic amendments can affect both survival of the pathogen in soil and infection of the host. Amendment of soil with compost or manure (Schönfeld et al. 2003) or pig slurry (Gorissen et al. 2004) reduced soil pathogen populations depending on soil type (Domõnguez et al. 2001; Kelman 1953; Michel and Mew 1998). These effects have been attributed to abundance of antagonistic microbial populations (Schönfeld et al. 2003; van Elsas et al. 2005), a microbial community shift (Gorissen et al. 2004), or ammonia toxicity (Michel and Mew 1998).

Management of bacterial wilt is especially important for small farmers in tropical countries, where the disease is endemic, including the Nile Delta area in Egypt, where the 'potato-specific' race 3 biovar 2 is common since the 1940s (Farag et al. 1999). Frequent interception of this quarantine pathogen after import of Egyptian early consumption potatoes has prompted the EU to ban importation of potatoes from the Nile Delta area (Anon. 1998). Export of Egyptian potatoes to the EU, however, is allowed from specially designated pest-free areas (PFAs) known as uncontaminated areas. These are mostly recently developed desert areas with sandy soils, which are pivotirrigated mainly with ancient water from a large uncontaminated aquifer. Of course, in the case of accidental introduction of $R$. solanacearum into the desert area, it would be important to know what the disease risk would be and what farmers could do to reduce this risk.

In view of the potential suppressive effects of soil amendments, it would be interesting to know if organic management could lead to a reduction in bacterial wilt. Root diseases and wilts caused by fungi are frequently well controlled in organicallymanaged soils (van Bruggen and Termorshuizen 2003), but this has not been studied for bacterial diseases. 
We previously studied the effects of organic versus conventional management, different soil types, and amendment with NPK fertilizer or cow manure on survival of $R$. solanacearum race 3 biovar 2 (Messiha 2006). The decline in $R$. solanacearum was faster in sandy than in clay soils; management effects were much smaller than effects of soil type. Application of NPK fertilizer or cow manure enhanced the decline rate of $R$. solanacearum. Survival of the pathogen in soil was positively correlated with total soluble organic matter and negatively with bacterial diversity as estimated from results of denaturing gradient gel electrophoresis (DGGE) of eubacterial 16S rDNA directly extracted from soil (Messiha 2006).

The main aim of this study was to investigate if soil management could affect potato brown rot development. Both management types (organic and conventional) and individual management components (fertilization of conventional soil with NPK and amendment of organic soil with manure or compost) were compared in sandy and clay soils from Egypt and the Netherlands. Various factors that could possibly explain differences in potato brown rot development in the different soils were assessed, e.g. soil physical and chemical characteristics and bacterial diversity in the bulk soil and rhizosphere of healthy potato plants grown in the various soils inoculated with $R$. solanacearum.

\section{Materials and methods}

Soils and amendments

Four pairs of soil were used: two pairs originated from Egypt, the two others were from the Netherlands. For each country half of the soils were sandy and half were clay. Two management regimes were selected, conventional versus organic. (Table 1). For repetition of the experiments the soils were sampled three times, in July 2003, March 2004, and February 2005 (experiments 1, 2 and 3, respectively). Twentyfive kilogram of soil was collected at random sampling points in $100 \mathrm{~m}^{2}$ plots down to $15-25 \mathrm{~cm}$ with an augur and mixed. Samples were transported in plastic bags in containers with ice. Egyptian soils were sent to the Netherlands in plastic bags in styrofoam boxes by overnight express airmail. Upon arrival in the laboratory each soil sample was thoroughly mixed and plant parts and earthworms were removed. The soils were stored at $4{ }^{\circ} \mathrm{C}$ until the start of the experiment.

To test the effect of different soil amendments (experiments 2 and 3), soils were left non-amended or were supplemented with $170 \mathrm{~kg} \mathrm{~N} \mathrm{ha}^{-1}\left(0.1 \mathrm{~g} \mathrm{~N} \mathrm{~kg}^{-1}\right.$ soil), the maximum amount that could be applied in manure according to EU regulations. Conventional soils were amended with NPK fertilizer $(12 \% \mathrm{~N}=7 \%$ ammonium $+5 \%$ nitrate; $10 \% \mathrm{P} ; 18 \% \mathrm{~K}$; $0.09 \mathrm{~g} \cdot 100 \mathrm{~g}^{-1}$ soil) or left non-amended. Organic

Table 1 Origin of soil samples

\begin{tabular}{lllllll}
\hline Sample & Code & Country & Soil type & Management & Previous and actual crops at time of sampling & Location \\
\hline 1 & ESC $^{\mathrm{a}}$ & Egypt & Sand & Conventional & Potatoes $^{\mathrm{b}, \mathrm{c}, \mathrm{d}, \mathrm{e}}$ & Nubaria, desert area \\
2 & ESO & Egypt & Sand & Organic & Potatoes $^{\mathrm{b}, \mathrm{c}, \mathrm{d}, \mathrm{e}}$ & Nubaria, desert area \\
3 & ECC & Egypt & Clay & Conventional & Beans $^{\mathrm{b}}$, potatoes $^{\mathrm{c}, \mathrm{d}, \mathrm{e}}$ & Behera, Delta area, \\
4 & ECO & Egypt & Clay & Organic & Potatoes $^{\mathrm{b}, \mathrm{c}, \mathrm{d}, \mathrm{e}}$ & Kaliobia, Delta area, \\
5 & NSC & NL & Sand & Conventional & Grass $^{\mathrm{b}}$, unplanted $^{\mathrm{c}, \mathrm{d},}$ & Marknesse, Northeast polder \\
6 & NSO & NL & Sand & Organic & Grass $^{\mathrm{b}, \mathrm{c}, \mathrm{d}}$ & Marknesse, Northeast polder \\
7 & NCC & NL & Clay & Conventional & Winter wheat $^{\mathrm{b}}$, seed potatoes $^{\mathrm{c}}$, sugar beet $^{\mathrm{d}}$ & Ens, Northeast polder \\
8 & NCO & NL & Clay & Organic & Grains $^{\mathrm{b}}$, onions $^{\mathrm{c}}$, beans $^{\mathrm{d}}$ & Ens, Northeast polder \\
\hline
\end{tabular}

${ }^{a}$ The first letter stands for the country of origin (Egypt or the Netherlands), the second for soil type (clay or sand), and the third for management type (conventional or organic)

b In 2003

c In 2004

d In 2005

e In the Egyptian fields, potatoes were still there or had just been harvested 
soils were amended with compost (Compost 8.1S, made from $88 \%$ wood chips, $2.5 \%$ manure and $10 \%$ clay with $0.61 \%$ of total $\mathrm{N}$ content; $1.7 \mathrm{~g}$ compost $\cdot 100 \mathrm{~g}^{-1}$ soil) or manure (organic cow manure with $0.48 \%$ of total $\mathrm{N}$ content; $2.17 \mathrm{~g} \cdot 100 \mathrm{~g}^{-1}$ soil) or left non-amended.

\section{Soil characterization}

For physical soil analysis, $100 \mathrm{~g}$ samples of nonamended soils were air-dried at room temperature. Fractions of different soil particle sizes were determined with a Coulter LS230 particle size analyzer (Beckman Coulter, Inc., Fullerton CA, USA). The method used was obtained from the manual of the Coulter grain-sizer type of 230. Particle sizes of $<2 \mu \mathrm{m}$ were considered clay, $2-50 \mu \mathrm{m}$ was considered silt and 50-2000 $\mu \mathrm{m}$ was considered sand (Table 2).

For chemical soil analysis, $100 \mathrm{~g}$ samples of nonamended and amended soils were air-dried at room temperature. $\mathrm{N}-\mathrm{NO}_{3}$ and $\mathrm{N}-\mathrm{NH}_{4}$ were extracted with $0.01 \mathrm{M} \mathrm{CaCl}_{2}$ and total $\mathrm{P}$ was extracted with $0.01 \mathrm{M}$ $\mathrm{H}_{2} \mathrm{SO}_{4}$ before spectrophotometrical analysis with a Segmented Flow Analyzer (Skalar Analytical BV, Breda, the Netherlands). Total $\mathrm{N}$ and organic $\mathrm{C}$ contents were determined with a CHN1110 Element Analyzer (CE Instruments, Milan, Italy). Dissolved Na and $\mathrm{K}$ were determined after sample extraction with $0.01 \mathrm{M} \mathrm{CaCl}_{2}$, vapourized, and analyzed by flame emission spectrophotometer at a wavelength of $589.0 \mathrm{~nm}$ for $\mathrm{Na}$ and $766.5 \mathrm{~nm}$ for K. Since $\mathrm{Ca}$ can interfere with $\mathrm{Na}$ analysis, $\mathrm{Ca}$ was bound in $\mathrm{Ca}-\mathrm{Al}$ complexes by adding aluminum salt (Houba et al. 1989). The $\mathrm{pH}$ was measured after $0.01 \mathrm{M} \mathrm{CaCl}_{2}$ extraction using a $\mathrm{pH} / \mathrm{mV}$ meter and combined electrode (Houba and Novozamsky 1998). Organic matter was determined by loss-on-ignition i.e. by dry combustion of the organic material in a furnace at 500$550^{\circ} \mathrm{C}$ and the loss in weight indicated the content of organic matter in the sample (Houba et al. 1997). Electric conductivity was determined according to ISO 7888-1985 (Water quality-Determination of electrical conductivity) and ISO 3696-1987 (Water for analytical laboratory use-Specification and test methods).

Microbial characterization-DGGE analysis

Total DNA was extracted from $0.5 \mathrm{~g}$ (wet weight) soil samples from bulk soil (at the beginning of experiment 3) or rhizosphere soil (at the end of experiment 3) with the Bio101 FastDNA ${ }^{\circledR}$ SPIN Kit for soil according to the manufacturer's specifications (Bio101, Carlsbad, CA, USA); a 20 min incubation time at $65^{\circ} \mathrm{C}$ was added to enhance the elution. The DNA quality and quantity were checked (Sambrook et al. 1989) on $1.2 \%$ agarose gels with ethidium bromide and visualized by UV trans-illumination.

For DGGE analysis of the eubacterial soil population, PCR amplification of the V6 to V8 region of the 16S rRNA gene from total soil DNA was conducted as described previously (Hiddink et al. 2005). DNA extracts from rhizosphere were diluted ten times more than for bulk soil to have the same amount of extracted DNA (about $2 \mathrm{ng}$ ). Extracted DNA samples of different managements and amendments within the same soil type from the same country of origin were loaded on the same gel at least twice. DGGE was carried out using the Dcode system (BIOrad Laboratories, Hercules, CA, USA). The silver stained and scanned gels were analysed with Phoretix 1D (NonLinear Dynamics Ltd., Newcastle upon Tyne, UK).

The bacterial diversity in the samples was estimated in two ways: as species richness $S$, and as the Shannon-Wiener index of bacterial diversity, $H^{\prime}$ as described previously (van Diepeningen et al. 2006).

Bacterial strains and inoculation

A mixture of equal amounts of three virulent $R$. solanacearum race 3 biovar 2 strains able to use nitrate as electron acceptor: PD5239, PD5240 and PD5241 (culture collection, Plant Protection Service, Wageningen, the Netherlands) were used in this study. These strains were of Egyptian origin, isolated from infected potato tubers. The cultures used for soil infestation were grown for $48 \mathrm{~h}$ on nutrient agar (NA) plates at $28^{\circ} \mathrm{C}$. The bacterial culture was suspended in $0.01 \mathrm{M}$ phosphate buffer (PB) and the bacterial density was adjusted using a spectrophotometer $\left(\mathrm{OD}_{600}=2.1\right.$

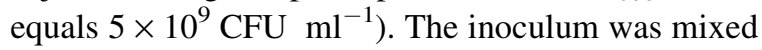
with the soil to have a final bacterial density of $10^{7} \mathrm{CFU} \mathrm{g}{ }^{-1}$ dry soils. The moisture content varied for each soil, but was at about field capacity for all soils.

\section{Experimental set-up}

The experiments were conducted three times for differently managed soils (experiments 1, 2 and 3) 


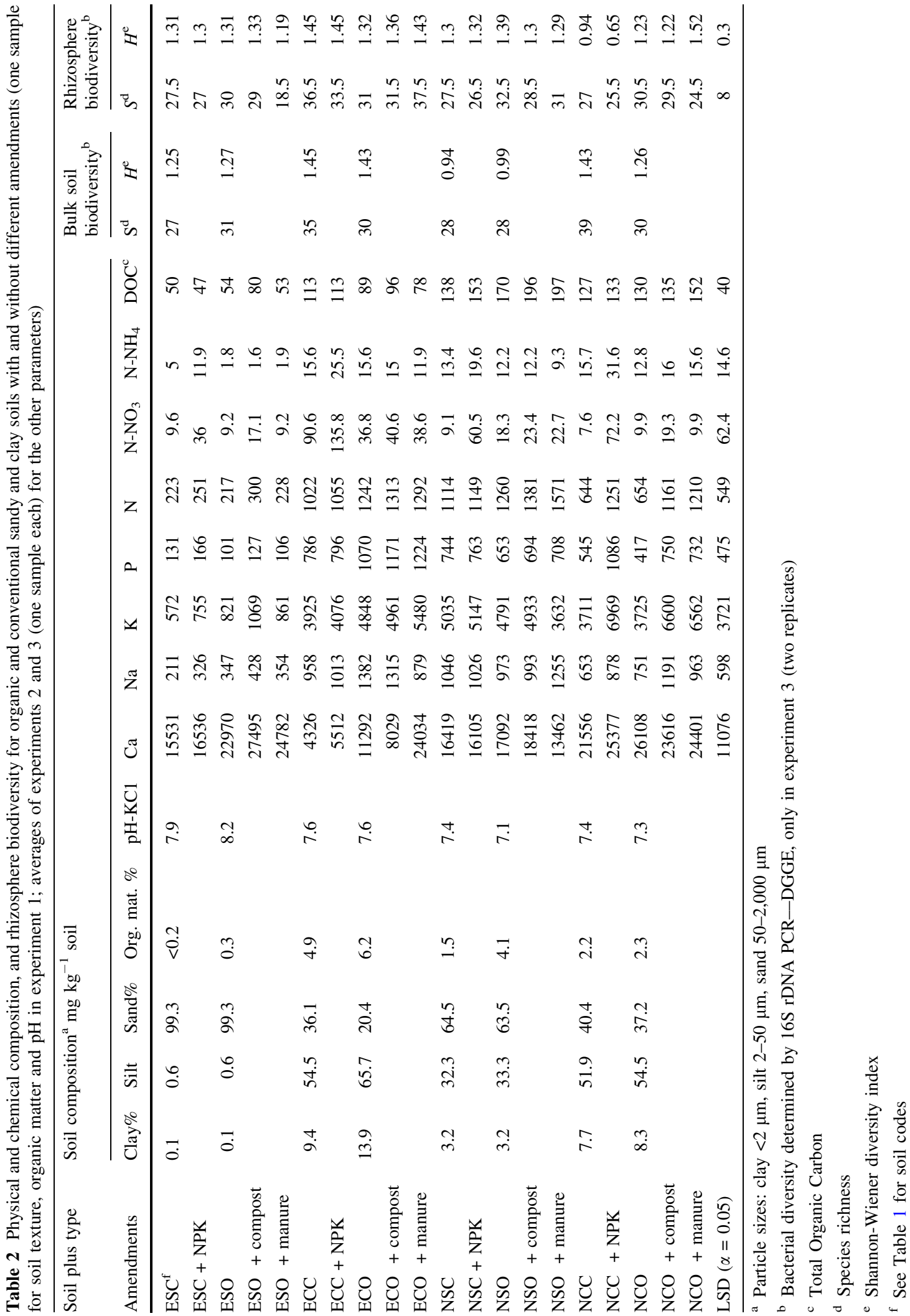


and two times (experiments 2 an 3) for differently amended soils in the quarantine greenhouse of the Plant Protection Service (PD) in Wageningen, The Netherlands. The susceptible potato variety Nicola was used in all experiments. In each experiment, six replicate pots were used per treatment, and two tuber eyepieces were planted per pot one day after inoculation of the soil. Two pots with non-inoculated soil per treatment were included as controls. The pots were placed on saucers, filled with water daily, keeping the soil moisture as constant as possible. The conditions of the greenhouse were adjusted to $25^{\circ} \mathrm{C}$ during the day and $20^{\circ} \mathrm{C}$ during the night, with a $\mathrm{RH}$ of $75-80 \%$ and a total of $14 \mathrm{~h} \mathrm{light} \mathrm{d}^{-1}$.

\section{Monitoring the disease}

Disease development was monitored daily. Wilt was scored according to \% wilted leaves relative to the total number of leaves per pot. Infection in the lower stem area (crown area) of each plant (with symptoms and latently infected) was checked at the end of the experiment (35 days). Infection was tested by plating the cut, weighed, and surface-sterilized plant tissues from the crown area (chopped in phosphate buffer saline PBS $0.01 \mathrm{M}$ ) on modified Selective Media South Africa (SMSA) plates (Anon. 1998). From all plant samples three ten-fold serial dilutions were plated (100 $\mu \mathrm{l}$ per plate) and the recovered $R$. solanacearum bacteria were counted after 5-7 days of incubation at $28^{\circ} \mathrm{C}$.

Population densities of the pathogen were determined in rhizosphere soil of potato plants and in bulk soil at the end of each experiment. Ten-fold serial dilutions were made of $1 \mathrm{~g}$ of rhizosphere or $10 \mathrm{~g}$ of bulk soil in $0.05 \mathrm{M}$ sterile phosphate buffer and after shaking for $2 \mathrm{~h}$ at $15^{\circ} \mathrm{C}$ plated on SMSA agar plates. Plates were incubated at $28^{\circ} \mathrm{C}$ for 5-7 days. Putative $R$. solanacearum colonies (one from each treatment) were randomly tested for identity using Immunofluorescence Antibody Staining (Janse 1988).

\section{Statistical analysis}

Wilt severity was plotted over time and the Area Under the Disease Progress Curve (AUDPC) was calculated for each pot. AUDPC values and $\log$ transformed $(\log (\mathrm{x}+1))$ densities of $R$. solanacearum in bulk soil, in rhizosphere soil and in plant tissue were tested for normality. As these variables were generally not normally distributed, non-parametric analyses (NPar-Tests, Mann-Whitney Test) were conducted for AUDPC, $\log (\mathrm{CFU}+1)$ in soil, $\log (\mathrm{CFU}+1)$ in rhizosphere soil, and $\log (\mathrm{CFU}+1)$ in plant tissue using SPSS v 12 (SPSS Inc., Chicago, Illinois, USA) to test the effects of soil origin (countries), soil type, management, and amendment. $\chi^{2}$ tests were conducted on contingency tables with two categories of wilted or infected plants per pot (wilted/infected or not) and soils from different origin, type, management, and amendment using Microsoft Excel 2003 (Microsoft Corporation, Seattle, WA, USA).

All soil characteristics were subjected to ANOVA (post-hoc, LSD) to test for differences between soil and management types and amendments, using SPSS $\mathrm{v}$ 12. Correlation analyses between AUDPCs (or population densities of $R$. solanacearum in soil, rhizosphere or plant tissues) and chemical characteristics of the soils were also conducted in SPSS v 12.

Cluster analysis was carried out on the DGGE band intensities of all lanes on individual gels, representing the bacterial composition for different managements or amendments within the same soil type from the same country of origin, using the Phoretix software (Nonlinear Dynamics Ltd, Newcastle upon Tyne, UK).

\section{Results}

Disease incidence and severity in organic and conventional non-amended soils

Pathogen behaviour was assessed using six indicators for each pot: \% wilted and infected plants, AUDPC (based on disease severity), CFU in bulk soil, in rhizosphere, and inside plant tissue (lower stem).

Disease incidence and severity were not normally distributed, so that analysis of variance could not be carried out. $\chi^{2}$ tests on incidence classes showed that more plants were wilted $\left(\chi^{2}=24.33>16.27\right.$, $\alpha=0.001)$ and infected by $R$. solanacearum $\left(\chi^{2}=22.38>16.27, \alpha=0.001\right)$ when growing on Dutch sandy soils than plants growing on any of the other soils (Table 3). The number of wilted plants per pot was higher in organic than in conventional Dutch soils. This difference was just not significant for the sandy soil $\left(\chi^{2}=3.00<3.84, \alpha=0.05\right)$, but was 
Table 3 Contingency table for the effect of country of origin (Egypt or the Netherlands), soil type (clay or sand), and management (conventional or organic) on the number of pots distributed over three categories of bacterial wilt incidence on potato and number of plants from which $R$. solanacearum was isolated, 35 days after planting in three greenhouse experiments combined

\begin{tabular}{|c|c|c|c|c|c|c|}
\hline \multirow[t]{2}{*}{ Country and soil type } & \multicolumn{3}{|c|}{ No. of wilted plants per pot } & \multicolumn{3}{|c|}{ No. of infected plants per pot } \\
\hline & 0 & 1 & $>1^{\mathrm{a}}$ & 0 & 1 & $>1$ \\
\hline $\mathrm{ES}^{\mathrm{b}}$ & 26 & 5 & 5 & 20 & 6 & 10 \\
\hline $\mathrm{EC}$ & 24 & 5 & 7 & 17 & 6 & 13 \\
\hline $\mathrm{NS}^{\mathrm{c}}$ & 9 & 9 & 18 & 7 & 2 & 27 \\
\hline $\mathrm{NC}$ & 26 & 4 & 6 & 21 & 4 & 11 \\
\hline$\chi^{2 \mathrm{~d}}$ & 24.3 & & & 22.4 & & \\
\hline
\end{tabular}

\begin{tabular}{|c|c|c|c|c|c|c|}
\hline \multirow[t]{2}{*}{ Management $^{\mathrm{e}}$} & \multicolumn{3}{|c|}{ No. of wilted plants per pot } & \multicolumn{3}{|c|}{ No. of infected plants per pot } \\
\hline & 0 & 1 & $>1$ & 0 & 1 & $>1$ \\
\hline ESC & 12 & 3 & 3 & 7 & 4 & 7 \\
\hline ESO & 14 & 2 & 2 & 13 & 2 & 3 \\
\hline$\chi^{2 \mathrm{f}}$ & 0.35 & & & 3.40 & & \\
\hline ECC & 11 & 2 & 5 & 8 & 3 & 7 \\
\hline $\mathrm{ECO}$ & 13 & 3 & 2 & 9 & 3 & 6 \\
\hline$\chi^{2}$ & 1.45 & & & 0.14 & & \\
\hline NSC & 6 & 6 & 6 & 5 & 2 & 11 \\
\hline NSO & 3 & 3 & 12 & 2 & 0 & 16 \\
\hline$\chi^{2}$ & 3.00 & & & 2.21 & & \\
\hline $\mathrm{NCC}$ & 16 & 1 & 1 & 13 & 0 & 5 \\
\hline $\mathrm{NCO}$ & 10 & 3 & 5 & 8 & 4 & 6 \\
\hline$\chi^{2}$ & 4.05 & & & 1.28 & & \\
\hline
\end{tabular}

a 2 or 3 wilted or infected plants per pot

${ }^{\mathrm{b}}$ For soil codes see Table 1

c Significantly different from the other three soil types

d Significant when $\chi^{2}>16.27, \alpha=0.001$

e Conventional $(\mathrm{C})$ versus organic $(\mathrm{O})$

f Significant when $\chi^{2}>3.84, \alpha=0.05$, a trend when $\chi^{2}>2.71, \alpha=0.10$

significant for the clay soil $\left(\chi^{2}=4.05>3.84\right.$, $\alpha=0.05)$. The number of plants from which $R$. solanacearum was isolated was higher in the conventional Egyptian sandy soil than in its organic counterpart, while it was the reverse for the pair of Dutch sandy soils. However, the differences were only significant at $\alpha=0.1$ (Table 3). No management effects on disease incidence were observed for the other soil pairs.

Log-transformed AUDPC and CFUs were still not normally distributed, so that Mann-Whitney nonparametric tests were carried out. The median AUDPC for the plants growing on Egyptian soils and for those on Dutch conventional clay soils was 0 although disease did occur in some of the plants (Table 5). Most disease occurred in plants growing on Dutch sandy soils, irrespective of their type of management. AUDPC of plants growing on infested Dutch sandy soils were significantly higher than of those growing on infested Dutch clay soils or Egyptian soils $(P<0.001)$. Similarly, CFUs were higher in soil, rhizosphere, and potato stems for Dutch sandy soils ( $P=0.001$, in all cases). This is in agreement with the higher percentages of wilted and infected plants in Dutch sandy soils, as described above. Disease severity (AUDPC) and population densities of $R$. solanacearum in soil, rhizosphere and stem were slightly lower in the organic than in the 
conventional Egyptian sandy soil (not significant), while CFUs $\mathrm{g}^{-1}$ soil were higher in the organic Dutch sandy and clay soils $(P=0.05)$. Thus, there was a tendency that the pathogen and disease development were reduced in organic Egyptian sandy soil and increased in Dutch organic and conventional sandy soils (Tables 3 and 4).

Physical and chemical soil characteristics for nonamended soils

The clay soils from Egypt and the Netherlands did not differ substantially in their clay, silt, and sand content, while the sandy soils from the two countries had clearly different textures. The Egyptian sand was 99\% pure sand while the Dutch sandy soils contained $32-33 \%$ of silt (Table 2). The Egyptian soils (especially the sandy soils) had a slightly higher $\mathrm{pH}$ than the comparable Dutch soils $(P<0.001)$, but all soils were alkaline. The electric conductivity (EC) was between 0.12 and $0.31 \mathrm{mS} \mathrm{cm}{ }^{-1}$ for all differently managed soils except the Egyptian clay soils where it was $0.43 \mathrm{mS} \mathrm{cm}^{-1}$. Dutch sandy soils had generally higher nutrient (except $\mathrm{Ca}$ ) and DOC contents $(P \leq 0.001)$ than Egyptian sandy soils. Dutch clay soils had a higher $\mathrm{Ca}$ and DOC content $(P<0.001$ and 0.04 , respectively), but lower $\mathrm{OM}$ and nitrate content than Egyptian clay soils $(P<0.001$ and 0.006, respectively). Egyptian clay soils had higher
OM, DOC and general nutrient contents $(P \leq 0.001)$ than Egyptian sandy soils, while Egyptian sandy soils contained more $\mathrm{Ca}(P=0.008)$ than Egyptian clay soils. The Dutch clay soil had a higher Ca content $(P=0.018)$ compared to the Dutch sandy soil. Organic soils from Egypt had higher $\mathrm{Ca}, \mathrm{Na}$ and $\mathrm{K}$ contents $(P<0.05$ to $<0.001)$ than their conventional counterparts, while the conventional sandy soil contained more ammonium $(P=0.012)$ than its organic counterpart. For Dutch soils, the nitrate content was significantly higher in the organic than in the conventional sandy soil $(P=0.002)$.

Overall, there were signiciant positive correlations between DOC and AUDPC, final disease severity and $\%$ wilted and infected plants $(P=0.009$ to 0.034$)$. There were negative correlations between $\mathrm{pH}$ and AUDPC, disease severity, wilt incidence, number of infected plants and $R$. solanacearum density in soil at the end of the experiment $(P=0.004$ to 0.043 ).

For the Dutch soils, where the disease was lower in the clay than in the sandy soils (Table 3), availability of $\mathrm{Ca}$ and $\mathrm{K}$ in non-amended soils was negatively correlated with the AUDPC ( $r=-0.51, P=0.045$ and $r=-0.50, P=0.051$, respectively). There were significant $(P<0.05)$ positive correlations between $\mathrm{Na}$ and \% infected plants, $\mathrm{CFU}$ in soil and CFU in rhizosphere, and negative $(P<0.05)$ correlations between ammonium and AUDPC, disease severity, and incidence of wilt and infected plants. On the

Table 4 Effect of organic versus conventional management on potato brown rot, AUDPC and CFU $\mathrm{g}^{-1}$ of soil, rhizosphere soil and per plant $(\log$ transformed +1$), 35$ days after planting of potato in three greenhouse experiments (data combined)

\begin{tabular}{|c|c|c|c|c|c|c|c|c|c|c|c|c|}
\hline \multicolumn{3}{|c|}{ AUDPC } & \multicolumn{3}{|c|}{ CFU $\mathrm{g}^{-1}$ soil } & \multicolumn{3}{|c|}{ CFU $\mathrm{g}^{-1}$ rhizosphere } & \multicolumn{4}{|c|}{$\mathrm{CFU} \mathrm{g}^{-1}$ plant } \\
\hline $\begin{array}{l}\text { Soil } \\
\text { type }\end{array}$ & Median & $\begin{array}{l}5 \% \\
\text { Trimmed } \\
\text { mean }\end{array}$ & $\begin{array}{l}\text { Mean } \\
\text { rank }\end{array}$ & Median & $\begin{array}{l}5 \% \\
\text { Trimmed } \\
\text { mean }\end{array}$ & $\begin{array}{l}\text { Mean } \\
\text { rank }\end{array}$ & Median & $\begin{array}{l}5 \% \\
\text { Trimmed } \\
\text { mean }\end{array}$ & $\begin{array}{l}\text { Mean } \\
\text { rank }\end{array}$ & Median & $\begin{array}{l}5 \% \\
\text { Trimmed } \\
\text { mean }\end{array}$ & $\begin{array}{l}\text { Mean } \\
\text { rank }\end{array}$ \\
\hline $\mathrm{ESC}^{\mathrm{c}}$ & 0 & 83.06 & 67.28 & 4.14 & 2.83 & 67.64 & 5.97 & 4.65 & 64.58 & 2.79 & 3.13 & 70.64 \\
\hline ESO & 0 & 17.78 & 55.03 & 0.39 & 1.78 & 52.83 & 2.78 & 3.12 & 49.81 & 0 & 1.57 & 53.44 \\
\hline ECC & 0 & 63.98 & 68.08 & 4.05 & 2.93 & 70.81 & 6.18 & 4.65 & 71.47 & 3.46 & 3.26 & 73.03 \\
\hline ECO & 0 & 59.07 & 62.94 & 1.38 & 2.02 & 55.22 & 5.61 & 4.94 & 71.58 & 3.12 & 3.22 & 74.11 \\
\hline NSC & 133.5 & 177.25 & 91.17 & 4.84 & 3.67 & $86.36^{\mathrm{a}}$ & 6.81 & 6.33 & 88.56 & 4.92 & 4.43 & 88.81 \\
\hline NSO & 348.5 & 375.56 & 109.92 & 5.45 & 5.08 & $111.94^{\mathrm{a}}$ & 7.67 & 7 & 105.11 & 7.06 & 5.48 & 100.11 \\
\hline NCC & 0 & 11.79 & 50.22 & 2.55 & 2.30 & $55.50^{\mathrm{b}}$ & 5.31 & 4.08 & 55.67 & 0 & 1.41 & 52.83 \\
\hline $\mathrm{NCO}$ & 12.25 & 91.16 & 75.36 & 4.30 & 3.68 & $79.69^{\mathrm{b}}$ & 5.95 & 5.32 & 73.22 & 0 & 2.57 & 67.03 \\
\hline
\end{tabular}

\footnotetext{
${ }^{a}$ Significant difference between organic and conventional soils at $\alpha=0.05$

b Same as under ${ }^{\mathrm{a}}$

c For soil codes see Table 1
} 
Table 5 Contingency table for the effect of amendment on the number of pots distributed over three categories of bacterial wilt incidence on potato and number of plants from which $R$. solanacearum was isolated, 35 days after planting in two greenhouse experiments (data of experiments 2 and 3 combined)

\begin{tabular}{|c|c|c|c|c|c|c|}
\hline \multirow{2}{*}{$\begin{array}{l}\text { Country and soil type }{ }^{\mathrm{a}} \\
\text { Amendment }^{\mathrm{b}}\end{array}$} & \multicolumn{3}{|c|}{ No. of wilted plants per pot } & \multicolumn{3}{|c|}{ No. of infected plants per pot } \\
\hline & 0 & 1 & $>1^{\mathrm{c}}$ & 0 & 1 & $>1$ \\
\hline ESC & 8 & 1 & 3 & 5 & 0 & 7 \\
\hline ESCN & 12 & 0 & 0 & 9 & 0 & 3 \\
\hline$\chi^{2, \mathrm{~d}}$ & 3.8 & & & 2.74 & & \\
\hline ESO & 10 & 1 & 1 & 10 & 0 & 2 \\
\hline ESOM & 11 & 0 & 1 & 10 & 0 & 2 \\
\hline$\chi^{2}$ & 0.05 & & & 0 & & \\
\hline ECC & 9 & 2 & 1 & 6 & 0 & 6 \\
\hline ECCN & 12 & 0 & 0 & 11 & 0 & 1 \\
\hline$\chi^{2}$ & 1.43 & & & 5.04 & & \\
\hline ECO & 7 & 4 & 1 & 7 & 1 & 4 \\
\hline ECOM & 10 & 2 & 0 & 10 & 0 & 2 \\
\hline$\chi^{2}$ & 1.53 & & & 1.2 & & \\
\hline NSC & 6 & 3 & 3 & 5 & 0 & 7 \\
\hline NSCN & 7 & 1 & 4 & 9 & 0 & 3 \\
\hline$\chi^{2}$ & 0.22 & & & 2.74 & & \\
\hline NSO & 3 & 3 & 6 & 2 & 0 & 10 \\
\hline NSOM & 8 & 0 & 4 & 8 & 0 & 4 \\
\hline$\chi^{2}$ & 2.67 & & & 6.17 & & \\
\hline NCC & 11 & 0 & 1 & 8 & 0 & 4 \\
\hline NCCN & 7 & 2 & 3 & 7 & 2 & 3 \\
\hline$\chi^{2}$ & 14.19 & & & 0.44 & & \\
\hline $\mathrm{NCO}$ & 8 & 4 & 0 & 7 & 1 & 4 \\
\hline NCOM & 11 & 0 & 1 & 10 & 0 & 2 \\
\hline$\chi^{2}$ & 1.47 & & & 1.2 & & \\
\hline
\end{tabular}

${ }^{a}$ For soil codes see Table 1

b Amendment with NPK $(\mathrm{N})$ or manure $(\mathrm{M})$ : the last letter of the soil code

b 2 or 3 wilted or infected plants per pot

c $\chi^{2}<3.84$ not significant, $\chi^{2}>2.71$ is a trend $\alpha=0.10$

other hand, there were positive correlations of nitrate with AUDPC, disease severity, and incidence of wilt and infected plants $(P=0.003$ to 0.018$)$.

For Egyptian soils, fewer correlations were found, e.g. a positive correlation between nitrate and CFU in plant tissue $(r=0.53, P=0.037)$ and a positive correlation between DOC and disease severity $(r=0.50, P=0.047)$.

Biological characteristics of non-amended soils

One bulk soil sample of each of the different soils from each country was included in duplicate in the
DGGE analysis. In general, biodiversity [S] and Shannon Wiener Index $\left[H^{\prime}\right]$ had higher values in clay than in sandy soils in both countries (Table 2). The organic Egyptian sandy soil had a higher diversity compared to the conventional counterpart, while the organic Egyptian clay soil had lower diversity than its conventional counterpart. There were no clear differences between organic and conventional Dutch sandy soils, while the organic Dutch clay soil had also less biodiversity compared to the conventional counterpart. These results were in agreement with the biodiversity data for the same soils used in experiments on survival of $R$. solanacearum (Messiha 
2006), except that in the latter study the Dutch organic clay soil had higher diversity compared to the conventional counterpart.

Cluster analysis of DGGE banding patterns of 16S-rDNA extracted from the rhizosphere of potatoes grown in the different soils resulted in a clustering according to organic or conventional management (Messiha 2006). There were no significant differences in microbial community composition between rhizosphere and bulk soil for any of the soils as detected with DGGE (data not shown). There was a clear shift in microbial biodiversity after cow manure amendment especially for sandy soils from both countries (Fig. 1A and B).

Disease incidence and severity in amended soils

Fertilization of conventional soils with NPK suppressed the disease in some cases. NPK-amendment to Egyptian sandy soil reduced wilt severity at the end of the experiment by $100 \%$ (from $18.8 \%$ to $0 \%$; $\left.\chi^{2}=3.8, \alpha=0.05\right)$ (Table 5), $R$. solanacearum density in stem tissues by $67.6 \%$ and AUDPC by $100 \%$ ( $P=0.02$ and $P=0.033$, respectively) (Table 6). NPK-amendment to Egyptian clay soil reduced \% infected plants by $84 \%\left(\chi^{2}=5.04>4.02, \alpha=0.025\right)$ (Table 6) and CFU of $R$. solanacearum in bulk soil by $93 \%$, in the rhizosphere by $80 \%$, and in stem tissues by $90.1 \%(P<0.05)$, but not AUDPC $(P=0.07)$ (Table 6). On the other hand, NPK amendment to the Dutch sandy soils significantly increased the $\%$ wilted plants from $8.3 \%$ to $28.4 \%\left(\chi^{2}=14.19>10.83\right.$, $\alpha=0.001$ ) (Table 5) and final wilt severity from $4.3 \%$ to $27.1 \%$ (data not shown) in Dutch clay soils.

Amendment of organic soils with cow manure also suppressed brown rot in some cases. Manure amendment reduced soil CFU counts by $100 \%(P=0.031)$ in Egyptian sandy soil and rhizosphere CFU counts by $62 \%(P=0.045)$ in Egyptian clay soil (Table 6). Amendment of Dutch sandy soil with manure decreased the $\%$ infected plants from $83.3 \%$ to $33.3 \%\left(\chi^{2}=6.17>5.02, \alpha=0.025\right)$ (Table 5) as well
A
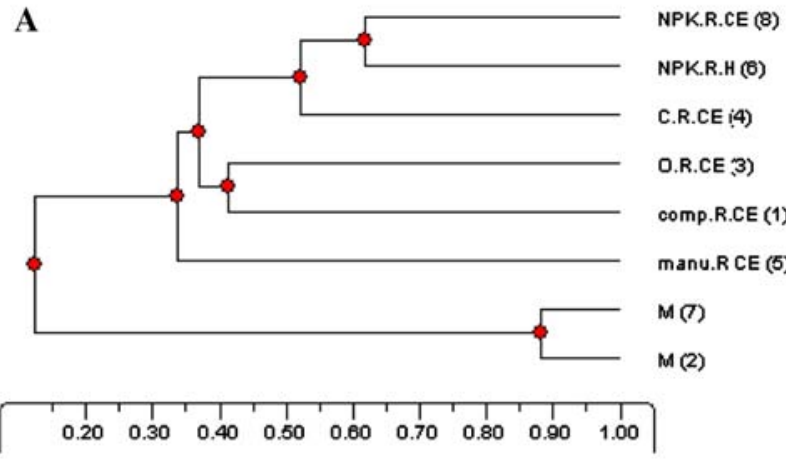

$$
\text { B }
$$
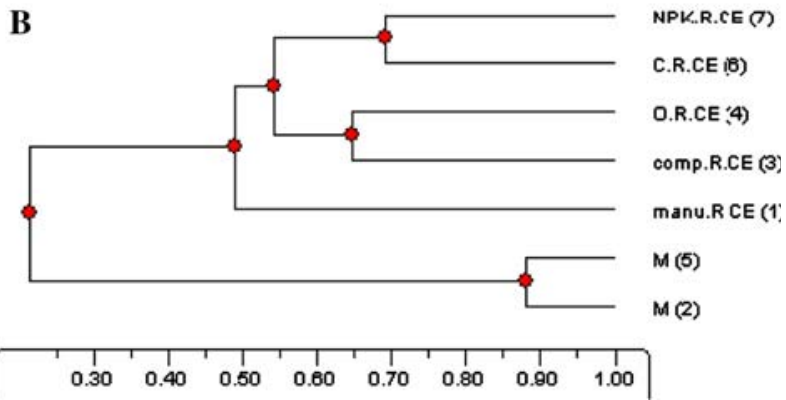

$\mathrm{O}=$ organic and $\mathrm{C}=$ conventional) or marker $(\mathrm{M})$, the second letters stand for rhizosphere (R) or bulk soil (B), the third letters for treatment $(\mathrm{H}=$ inoculated but healthy and $\mathrm{C}=$ noninoculated control), and the fourth letters for sampling time ( $\mathrm{B}=$ beginning and $\mathrm{E}=$ end). The numbers between brackets indicate the lane number on the gel 
Table 6 Effect of amendment with NPK to conventional soils and manure to organic soils on AUDPC, CFUs in bulk soil, rhizosphere soil and inside plant tissues (stem base), 35 days after planting potatoes in two greenhouse experiments (data of experiments 2 and 3 combined)

\begin{tabular}{|c|c|c|c|c|c|c|c|c|c|c|c|c|}
\hline \multicolumn{4}{|l|}{ AUDPC } & \multicolumn{3}{|c|}{ CFU $\mathrm{g}^{-1}$ soil } & \multicolumn{3}{|c|}{$\mathrm{CFU} \mathrm{g}^{-1}$ rhizosphere } & \multicolumn{3}{|c|}{$\mathrm{CFU} \mathrm{g}^{-1}$ plant } \\
\hline $\begin{array}{l}\text { Soil } \\
\text { type }\end{array}$ & Median & $\begin{array}{l}5 \% \\
\text { Trimmed } \\
\text { mean }\end{array}$ & $\begin{array}{l}\text { Mean } \\
\text { rank }\end{array}$ & Median & $\begin{array}{l}5 \% \\
\text { Trimmed } \\
\text { mean }\end{array}$ & $\begin{array}{l}\text { Mean } \\
\text { rank }\end{array}$ & Median & $\begin{array}{l}5 \% \\
\text { Trimmed } \\
\text { mean }\end{array}$ & $\begin{array}{l}\text { Mean } \\
\text { rank }\end{array}$ & Median & $\begin{array}{l}5 \% \\
\text { Trimmed } \\
\text { mean }\end{array}$ & $\begin{array}{l}\text { Mean } \\
\text { rank }\end{array}$ \\
\hline $\mathrm{ESC}^{\mathrm{a}}$ & 0 & 134.7 & $14.50 * \mathrm{~b}$ & 14.14 & 3.03 & 14.58 & 6.44 & 4.97 & 15.08 & 2.79 & 3.21 & $14.92 *$ \\
\hline $\mathrm{ESCN}^{\mathrm{d}}$ & 0 & 0.0 & $10.50 *$ & 0.00 & 1.06 & 10.42 & 1.51 & 2.71 & 9.92 & 0.00 & 1.04 & $10.08^{*}$ \\
\hline ESO & 0 & 11.6 & 12.92 & 0.00 & 1.85 & $15.00 *$ & 2.78 & 3.07 & 14.17 & 0.00 & 0.91 & 12.67 \\
\hline ESOM & 0 & 19.6 & 12.08 & 0.00 & 0.00 & $10.00^{*}$ & 0.00 & 1.11 & 10.83 & 0.00 & 0.64 & 12.33 \\
\hline $\mathrm{ECC}$ & 0 & 55.9 & 14.00 & 2.54 & 2.57 & $14.92 *$ & 3.08 & 3.50 & $14.92 *$ & 1.71 & 2.42 & $15.00 *$ \\
\hline $\mathrm{ECCN}$ & 0 & 0.0 & 11.00 & 0.00 & 0.19 & $10.08 *$ & 0.00 & 0.70 & $10.08 *$ & 0.00 & 0.22 & $10.00 *$ \\
\hline ECO & 0 & 59.1 & 13.00 & 0.00 & 1.69 & 13.58 & 5.61 & 4.57 & $15.25^{*}$ & 0.00 & 2.06 & 14.00 \\
\hline ECOM & 0 & 28.2 & 12.00 & 0.00 & 0.72 & 11.42 & 0.00 & 1.76 & $9.75 *$ & 0.00 & 0.62 & 11.00 \\
\hline NSC & 15 & 169.0 & 11.13 & 3.56 & 2.74 & 13.17 & 5.52 & 5.39 & 12.79 & 2.58 & 3.14 & 13.17 \\
\hline NSCN & 0 & 142.7 & 13.88 & 3.17 & 3.50 & 11.83 & 5.61 & 4.25 & 12.21 & 0.00 & 2.65 & 11.83 \\
\hline NSO & 495 & 386.8 & $15.17^{*}$ & 5.17 & 4.60 & 10.08 & 7.18 & 6.03 & 13.25 & 4.56 & 4.33 & 13.21 \\
\hline NSOM & 0 & 144.9 & $9.83 *$ & 5.95 & 5.72 & 14.92 & 5.05 & 4.74 & 11.75 & 3.60 & 3.44 & 11.79 \\
\hline NCC & 0 & 10.7 & 10.46 & 3.81 & 2.99 & 12.00 & 5.63 & 4.75 & 12.33 & 0.00 & 1.64 & 10.46 \\
\hline $\mathrm{NCCN}$ & 0 & 247.1 & 14.54 & 3.60 & 3.69 & 13.00 & 5.83 & 4.02 & 12.67 & 1.63 & 2.69 & 14.54 \\
\hline $\mathrm{NCO}$ & 0 & 114.0 & 13.92 & 3.96 & 3.38 & 13.92 & 5.60 & 4.61 & 13.75 & 0.00 & 2.57 & 13.79 \\
\hline NCOM & 0 & 11.5 & 11.08 & 3.01 & 2.56 & 11.08 & 3.97 & 3.83 & 11.25 & 0.00 & 0.94 & 11.21 \\
\hline
\end{tabular}

${ }^{\text {a }}$ For soil type see Table 1

b *Asymptotic significant difference between amended and unamended soils (2-tailed): $(P \leq 0.05)$

as the AUDPC by $52 \%(P=0.05)$ (Tables 5 and 6$)$ and final wilt severity from $47 \%$ to $20 \%$ (data not shown). Amendment of organic soils with compost had no effects on CFU of $R$. solanacearum or on brown rot incidence or severity (data not shown).

Physical and chemical soil characteristics of amended soils

Amendment of Egyptian conventional sandy soil with NPK increased the EC and significantly increased both the nitrate and the ammonium contents ( $P=0.028$ and $P=0.019$, respectively, Table 2 ). Amendment of Egyptian organic sandy soil with compost and cow manure significantly increased the DOC contents $(P=0.035$ and $P=0.023$ respectively). Amendment of Dutch organic clay soil with cow manure significantly increased the DOC content $(P=0.015)$. Amendments of the other soils did not affect the studied chemical characteristics of those soils. Correlations between soil characteristics and disease measurements or pathogen populations were similar for the data sets with and without amendments.

Biological characteristics of amended soils

Amendment of conventional soils with NPK and organic soils with compost did not affect the bacterial diversity in the rhizosphere (Table 2). On the other hand, amendment of organic soils with manure affected bacterial diversity in various ways. In the poor Egyptian sandy soils, rhizosphere bacterial diversity $[\mathrm{S}]$ decreased from $30.0 \pm 1.00$ to $18.5 \pm 0.50(P=0.001)$, indicating that some species grew at the cost of others thanks to the substrate added with the manure. In the Dutch clay soils, manure amendment decreased $(P=0.003)$ the rhizosphere [S] from $30.5 \pm 0.50$ to $24.5 \pm 0.50$, and increased rhizosphere $\left[H^{\prime}\right]$ from $1.23 \pm 0.3$ to $1.52 \pm 0.02(P=0.035)$. In Dutch sandy soils, the amendments did not affect bacterial diversity in the 
rhizosphere as determined with DGGE (data not shown).

\section{Discussion}

The main objective of this study was to investigate if organic management could reduce infection of potato by $R$. solanacearum and potato brown rot development, since root diseases caused by fungi are generally suppressed in organically-managed soils (van Bruggen and Termorshuizen 2003), and various bacterial wilt diseases can be suppressed by organic amendments (Gorissen et al. 2004; Islam and Toyota 2004; Satoh and Toyota 2004). In this study, there was only a tendency for reduced infection by $R$. solanacearum in plants grown on organic sandy soil from the Egyptian desert. The biodiversity in these poor desert soils was higher in the organicallymanaged soil, possibly leading to more competition for the limited substrate compared to the conventional soil (Messiha 2006). Availability of nutrients in potato root exudates may have overcome this competition, so that the difference between organically and conventionally-managed soils was just not significant any more in the rhizosphere.

Similar to our previous results on survival of the pathogen, both density in bulk soil and disease incidence (proportion of wilted plants) were higher in organic than in conventional sandy and clay soils from the Netherlands. This may be related to the high availability of substrate in the Dutch soils, especially the organically-managed soils, where large quantities of manure have commonly been used (van Diepeningen et al. 2006). Indeed, in this study the DOC content in soil was positively correlated with AUDPC, and was higher in the organic than in the conventional Dutch sandy soil. Cluster analysis for the DGGE bands of DNA samples from Dutch soils indicated that there was a rhizosphere effect in organic clay soil and not in conventional clay soil. This is the reverse of previous results, where a larger rhizosphere effect in terms of microbial communities was observed in soil from a conventional farm than in that from an organic farm (van Diepeningen et al. 2005). The lower disease incidence and severity in the conventional than in the organic soils in the current experiments are in agreement with the notion that a lower rhizosphere effect (as found in the conventional soil here), called 'root camouflage', would lead to less pathogen attraction and root disease (Gilbert et al. 1994).

A second objective was to determine if $R$. solanacearum and potato brown rot could be suppressed by various organic amendments. Amendment of cow manure to organically-managed soil gave significant disease suppression in the sandy soil from the Netherlands and a significant reduction in density of $R$. solanacearum in the organic sandy soil from Egypt. No significant effects were found for the clay soils. Satoh and Toyota (2004) also found that the effect of repeated manure amendments on bacterial wilt development (on tomato) varied from soil to soil. The suppressive effects of manure added to organic sandy soils from the Netherlands and Egypt could have been due to the immediate release of ammonia, which is known to be toxic to microorganisms (Michel and Mew 1998) or to a shift in the microbial community (Gorissen et al. 2004). The bacterial diversity in the rhizosphere was not changed by manure amendment to Dutch sandy soil, but bacterial composition did change (Fig. 3b). Effects of bacterial composition rather than diversity on root disease suppression has been documented earlier (Hoitink and Boehm 1999). In the poor Egyptian sandy soils, rhizosphere bacterial composition also changed after manure amendment (Fig. 1b), and diversity decreased, indicating that some, likely fast-growing species, increased at the cost of others thanks to the substrate added with the manure. In clay soils both from Egypt and the Netherlands, the Shannon-Wiener index increased after manure amendment, and no significant effects on potato brown rot were found. Thus, the effects of manure on $R$. solanacearum may be caused by effects on survival (reduced CFU in Egyptian sandy soil), ammonia volatilisation or higher microbial activity by a limited number of fast-growing bacteria (Islam and Toyota 2004), or effects on pathogen growth in the rhizosphere and infection (reduced incidence and severity in Dutch sandy soil), again caused by ammonia production or specific inhibition by rhizosphere organisms.

Amendment of soils with wood chip compost was not effective in potato brown rot suppression (data not shown). Similarly, compost from tree bark or coffee residues did not suppress, but even enhanced bacterial wilt of tomato, while compost from farm- 
yard manure plus rice straw and of poultry manure suppressed $R$. solanacearum in soil and reduced disease development (Islam and Toyota 2004). The suppressive effects of composted farmyard manure and poultry manure was attributed to high substrate availability with high $\mathrm{N}$ content (high DOC content, high available $\mathrm{N}$ content, and a low $\mathrm{C} / \mathrm{N}$ ratio), and high microbial activity (Islam and Toyota 2004). Others also showed that the disease-suppressive or enhancing effects of compost depend on their chemical and biological composition (Litterick et al. 2004), as well as on the pathogen involved (Termorshuizen et al. 2006). In all these studies, compost was added to conventional field soil or peat substrate, while we added compost to organic field soil, which was already relatively suppressive in the case of organic sandy soil from Egypt. Also, relatively small amounts of compost were added, in accordance with the stringent Dutch regulations, compared to other studies (Islam and Toyota 2004; Termorshuizen et al. 2006).

Amendment of conventional soils with NPK gave remarkable disease suppression only in Egyptian sandy soil and a reduction in $R$. solanacearum populations in soil, rhizosphere and potato plants in Egyptian clay soil. The $\mathrm{pH}$ of Egyptian soils was slightly, but significantly higher, especially for sandy soils (7.9-8.2), than that of Dutch soils (7.4). The observed disease suppression may be a result of higher ammonia concentrations at these $\mathrm{pH}$ levels (Kissel et al. 1985), which are toxic to $R$. solanacearum (Michel and Mew 1998). The effect of NPK amendment may be a combination between the effect of ammonia and potassium (K). Fertilization of potato plants with superphosphate $\left(15 \% \mathrm{P}_{2} \mathrm{O}_{5}\right)$ or potassium sulphate $\left(48-58 \% \mathrm{~K}_{2} \mathrm{O}\right)$ decreased incidence of brown rot disease (Fahmy and Mohamed 1990). Mixing NPK fertilizers with compost was most effective in suppressing bacterial wilt of banana (Roy et al. 1999) and brown rot of potato (Lemaga et al. 2005). On the other hand, amendment of conventional clay soil from the Netherlands with NPK increased \% wilted potato plants. It is not clear what the reason for this increase could be. The available nutrients and DOC were already high in the non-amended Dutch conventional clay soil, but this was also the case for the Egyptian conventional clay soil.

Another objective of this study was to relate brown rot development to various characteristics of different soil types from different locations, to find factors that might be associated with disease suppression. Disease severity was highest in Dutch sandy soils compared to all other soils. Chemical analysis revealed that the dissolved organic carbon (DOC) was the highest in these soils and was positively correlated with disease incidence, suggesting high substrate availability and better survival chances for $R$. solanacearum (Messiha 2006).

Compared to Dutch sandy soils, the disease was suppressed in Dutch clay soils, where the DOC was also relatively high, but both the $\mathrm{Ca}$ and $\mathrm{K}$ contents were remarkably higher in the Dutch clay compared to the sandy soils and were negatively correlated with disease incidence. Both $\mathrm{K}$ and $\mathrm{Ca}$ are known for enhancing plant defences (Flego et al. 1997). As mentioned above, fertilization with potassium sulphate reduced the incidence of brown rot on potato (Fahmy and Mohamed 1990). In our study, the $\mathrm{Ca}$ and $\mathrm{K}$ contents were also higher in organic than in conventional Egyptian sandy soil, and the proportion of $R$. solanacearum-infected plants was reduced in the organic soil, supporting previous findings about enhanced resistance in plants high in $\mathrm{Ca}$ and/or $\mathrm{K}$.

The Na contents were significantly higher in the Egyptian clay (especially the organic clay soil) and Dutch soils than in the sandy soils from Egypt, which also had low $R$. solanacearum populations and infection, (particularly in the organic sandy soil from Egypt). Thus, a positive correlation was found between $\mathrm{Na}$ availability and \% infected plants, CFU in the rhizosphere and CFU in the plant, which may explain the absence of disease suppression in the organic clay soil from Egypt even when both $\mathrm{Ca}$ and $\mathrm{K}$ concentrations were high. It is well known that root exudation is increased in sodic soils, enhancing the attraction for and susceptibility to various root diseases (Snapp et al. 1991).

The EC was highest in the Egyptian clay soils as compared to all other amended soils. In a previous study (Messiha 2006), the survival of $R$. solanacearum was higher in Egyptian clay soils compared to the sandy ones while in this study the disease expression was similar in both soil types. Also NPK fertilization showed noticeable increase of the EC, which was correlated with disease suppression.

In conclusion, contrary to our original expectation of disease suppression in organically-managed soils (van Bruggen and Termorshuizen 2003), populations 
of $R$. solanacearum were higher in the bulk soil and rhizosphere of potato plants grown in organic soils from the Netherlands, in particular organic sandy soil. Also disease incidence was higher in these organically-managed soils. This was probably related to the availability of substrate for growth of the pathogen in soil and the rhizosphere. Lack of substrate in the organically-managed Egyptian sandy soil due to high competition may have been responsible for the suppression in that soil compared to its conventional counterpart. When $\mathrm{Ca}$ and $\mathrm{K}$ contents of soils were high, potato brown rot incidence or severity was generally low, both in soils naturally high in these elements and in soils amended with manure. Application of NPK fertilizer reduced the disease, especially at high soil $\mathrm{pH}$ in Egyptian soils, probably due to ammonia volatilization. However, high fertilizer applications cannot be recommended for control of brown rot, as these may enhance susceptibility to other diseases, and would not be sustainable in the long run. Farmers could apply moderate levels of cow manure to reduce the disease, but to such a level that DOC content does not stimulate the pathogen. Application of composted poultry manure would be an interesting option to be explored for the Nile Delta of Egypt (Islam and Toyota 2004), but for the Egyptian desert and the Netherlands, prevention of spread and quarantine remain important tools to combat potato brown rot. This study shows that mechanisms of disease suppression of soil-borne plant pathogens may vary strongly according to the soil type, especially if quite different types of soil are under study.

Acknowledgements This project was funded by the EU through the EU-Egypt Potato Brown Rot Project Phase II (SEM03/220/51A / EGY 1B/1999/0192). We appreciate the advisory and technical help from the team at the Department of Bacteriology of the Plant Protection Service (PD), Wageningen, namely B. Briaire, G. Willemsen, K.P.J. Gaisch, J.G.B. Voogd, N.M. Landman, P. van de Werde, P.P.M.A. Gorkink-Smits, and S. Somovilla-Carrasco. We are thankful to H.D. Halm of the Biological Farming Systems Group for conducting the soil chemical analyses. We also appreciate the cooperative help from Dr S. Elhadad and Dr Faiza.G. Fawzy from the Potato Brown Rot Project in Egypt.

\section{References}

Anony. (1998) Interim testing scheme for the diagnosis, detection and identification of Ralstonia solanacearum (Smith) Yabuuchi et al. in potatoes. Annex II to the
Council Directive 98/57/EC of 20 July 1998 on the control of Ralstonia solanacearum (Smith) Yabuuchi et al. Publication 97/647/EC, Official Journal European Communities No. L235, 8-39.

Domõnguez, J., Negrõn, M. A., \& Rodrõguez, C. M. (2001). Aggregate water-stability, particle-size and soil solution properties in conducive and suppressive soils to Fusarium wilt of banana from Canary Islands (Spain). Soil Biology and Biochemistry, 33, 449-455.

Elphinstone, J. G. (2005). The current bacterial wilt situation: A global overview. In C. Allen, P. Prior, \& A. C. Hayward (Eds.), Bacterial wilt disease and the Ralstonia solanacearum species complex (pp. 9-28). USA: The American Phytopathological Society, St. Paul.

Elphinstone J. G., \& Aley P. (1993). Integrated control of bacterial wilt of potato in the warm tropics of Peru. In Hartman G. L. \& Hayward A. C. (Eds.) Bacterial wilt. ACIAR. Proceedings 45. ACIAR, (pp. 276-283) Canberra, Australia.

Farag, N. S., Stead, D. E., \& Janse, J. D. (1999). Ralstonia (Pseudomonas) solanacearum race 3, biovar 2, detected in surface (irrigation) water in Egypt. Journal of Phytopathology, 147, 485-487.

Fahmy, F. G., \& Mohamed, M. S. (1990). Some factors affecting the incidence of potato brown rot. Assuit Journal of Agricultural Science, 21, 221-230.

Flego, D., Pirhonen, M., Saarilahti, H., Palva, T. K., \& Palva, E. T. (1997). Control of virulence gene expression by plant calcium in the phytopathogen Erwinia carotovora. Molecular Microbiology, 25, 831-838.

French, E. R. (1994). Strategies for integrated control of bacterial wilt of potato. In A. C. Hayward, \& G. L. Hartman (Eds.), Bacterial wilt: The disease and its causative agent, Pseudomonas solanacearum (pp. 199-207). Wallingford, UK: CAB International.

Gilbert, G. S., Handelsman, J., \& Parke, J. L. (1994). Root camouflage and disease control. Phytopathology, 84, 222225.

Gorissen, A., van Overbeek, L. S., \& van Elsas, J. D. (2004). Pig slurry reduces the survival of Ralstonia solanacearum biovar 2 in soil. Canadian Journal of Microbiology, 50, 587-593.

Hartman, G. L., \& Elphinstone, J. G. (1994). Advances in the control of Pseudomonas solanacearum Race 1 in major food crops. In A. C. Hayward, \& G. L. Hartman (Eds.), Bacterial wilt: The disease and its causative agent, Pseudomonas solanacearum (pp. 157-177). Wallingford, United Kingdom: CABI International.

Hayward, A. C. (1991). Biology and epidemiology of bacterial wilt caused by Pseudomonas solanacearum. Annual Review of Phytopathology, 29, 65-87.

Hiddink, G. A., Termorshuizen, A. J., Raaijmakers, J. M., \& van Bruggen, A. H. C. (2005). Effect of mixed and single crops on disease suppressiveness of soils. Phytopathology, 95, 1325-1332.

Hoitink, H. A. J., \& Boehm, M. J. (1999). Biocontrol within the context of soil microbial communities: A Substratedependent phenomenon. Annual Review of Phytopathology, 37, 427-446.

Houba, V. J. G., \& Novozamsky, I. (1998). Influence of storage time and temperature of dry soils on $\mathrm{pH}$ and extractable 
nutrients using $0.01 \mathrm{~mol} / \mathrm{l} \mathrm{CaCl}$. Fresenius Journal of Analytical Chemistry, 360, 362-365.

Houba, V. J. G, van der Lee J. J., \& Novozamsky, I. (1997). Determination of organic matter content. Soil analysis procedures, other procedures, (soil and plant analysis, part 5B). Wageningen Agricultural University, Departement of Soil science and Plant Nutrition, Wageningen, pp. $38-40$.

Houba, V. J. G, van der Lee J. J., Novozamsky, I., \& Walinga, I. (1989). Determination of sodium and potassium. Soil analysis and plant analysis, a series of syllabi, part 5, Soil Analysis Procedure. Wageningen Agricultural University, Departement of Soil science and Plant Nutrition, Wageningen, pp. 15_10-15_15.

Islam, T. M. D. \& Toyota, K. (2004). Suppression of bacterial wilt of tomato by Ralstonia solanacearum by incorporation of composts in soil and possible mechanisms. Microbes and Environments, 19, 53-60.

Janse, J. D. (1988). A detection method for Pseudomonas solanacearum in symptomless potato tubers and some data on its sensitivity and specificity. Bulletin OEPP/ EPPO Bulletin, 18, 343-351.

Kelman A (1953) The bacterial wilt caused by Pseudomonas solanacearum. North Carolina Agricultural Experimental Station Technical Bulletin 99: 194 pp.

Kissel, D. E., Sander, D. H., \& Ellis, R. (1985). Fertilizer-plant interaction in alkaline soils. In O. P. Engelstad (Eds.), Fertilizer technology and use (pp. 153-196). Madison, WI: Soil Science Social American.

Lemaga, B., Kakuhenzire, R., Kassa, B., Ewell, P. T., \& Priou, S. (2005). Integrated control of potato bacterial wilt in Eastern Africa: The experience of African highlands initiative. In C. Allen, P. Prior, \& A. C. Hayward (Eds.), Bacterial wilt disease and the Ralstonia solanacearum species complex (pp. 145-157). Minnesota, USA: The American Phytopathological Society.

Litterick, A. M., Harrier, L., Wallace, P., Watson, C. A., \& Wood, M. (2004). The role of uncomposted materials, composts, manures, and compost extracts in reducing pest and disease incidence and severity in sustainable temperate agricultural and horticultural crop production-A Review. Critical Review in Plant Sciences, 23, 453-479.

Messiha N. A. S. (2006). Bacterial wilt of potato (Ralstonia solanacearum race 3, biovar 2): Disease management, pathogen survival and possible eradication. $\mathrm{PhD}$ Thesis, Wageningen University, The Netherlands, $151 \mathrm{pp}$.

Michel, V. V., \& Mew, T. W. (1998). Effect of soil amendment on the survival of Ralstonia solanacearum in different soils. Phytopathology, 88, 300-305.

Michel, V. V., Wang, J. F., Midmore, D. J., \& Hartman, G. L. (1997). Effects of intercropping and soil amendment with urea and calcium oxide on the incidence of bacterial wilt of tomato and survival of soil-borne Pseudomonas solanacearum in Taiwan. Plant Pathology, 46, 600-610.

Moffett, M. L., Giles, J. E., \& Wood, B. A. (1983), Survival of Pseudomonas solanacearum biovars 2 and 3 in soil:
Effect of moisture and soil type. Soil Biology and Biochemistry, 15, 587-591.

Roy, S., Ojha, P. K., Ojha, K. L., Upadhyay, J. P., \& Jha, M. M. (1999). Effect of mixed application of fertilizers and organic amendments on the disease intensity of wilt complexes in banana (Musa sp.). Journal of Applied Biology, 9, 84-86.

Sambrook, J., Fritsch, E. F., \& Maniatis, T. (1989). Molecular cloning. A laboratory Manual, 1, 6-7. Second edition. Cold Spring Harbor Laboratory Press, New York, USA.

Satoh, K., \& Toyota, K. (2004). Comparison of disease suppressiveness of different soils with or without repeated application of organic matters toward bacterial wilt of tomato caused by Ralstonia solanacearum. Microbes and Environments, 19, 310-314.

Schönfeld, J., Gelsomino, A., van Overbeek, L. S., Gorissen, A., Smalla, K., \& van Elsas, J. D. (2003). Effects of compost addition and simulated solarisation on the fate of Ralstonia solanacearum biovar 2 and indigenous bacteria in soil. FEMS Microbiological Ecology, 43, 63-74.

Snapp, S. S., Shennan, C., \& van Bruggen, A. (1991). Effects of salinity on severity of infection by Phytophthora parasitica Dast., ion concentrations and growth of tomato, Lycopersicon esculentum Mill. New Phytologist, 119, 275-284.

Termorshuizen, A. J., van Rijn, E., van de Gaag, D. J., Chen, Y., Lagerlof, J., Paplomatas, E. J., Ramert, B., Steinberg, C., Zmora, S. (2006). Disease suppression of 18 composts against 7 pathogens. Soil Biology and Biochemistry, 38, 2461-2477.

van Bruggen, A. H. C., \& Termorshuizen, A. J. (2003). Integrated approaches to root disease management in organic farming systems. Australasian Journal of Plant Pathology, 32, 141-156.

van Diepeningen, A. D., de Vos, O. J., Korthals, G. W., \& van Bruggen, A. H. C. (2006). Effects of organic versus conventional management on chemical and biological parameters in agricultural soils. Applied Soil Ecology, 31, 120-135.

van Diepeningen, A. D., de Vos, O. J., Zelenev, V. V., Semenov, A. M., \& van Bruggen, A. H. C. (2005). DGGE fragments oscillate with or counter to fluctuations of cultivable bacteria along wheat roots. Microbial Ecology, 50, 506-517.

van Elsas, J. D., Kastelein, P., van Bekkum, P., van der Wolf, J. M., de Vries, P. M., \& van Overbeek, L. S. (2000). Survival of Ralstonia solanacearum biovar 2, the causative agent of potato brown rot, in field and microcosm soils in temperate climates. Phytopathology, 90, 1358-1366.

van Elsas, J. D., van Overbeek, L. S., Bailey, M. J., Schönfeld, J., \& Smalla, K. (2005). Fate of Ralstonia solanacearum biovar 2 as affected by conditions and soil treatments in temperate climate zones. In C. Allen, P. Prior, \& A. C. Hayward (Eds.), Bacterial wilt disease and the Ralstonia solanacearum species complex (pp. 39-49). Minnesota, USA: The American Phytopathological Society. 